\title{
Effect of Herbal Liver Tonic on the Growth, Digestibility and Bio-chemical Composition of Grey Mullet Mugil cephalus (Linnaeus) Fry
}

\author{
P.P. Patel ${ }^{1 *}$, M.P. Patel ${ }^{2}$ and P.R. Tank ${ }^{2}$ \\ ${ }^{1}$ Krishi Vigyan Kendra, Navsari Agricultural University, Navsari-396450, India \\ ${ }^{2}$ Fisheries Research Station, Junagadh Agricultural University, Okha-Port-361350, India \\ *Corresponding author
}

\section{A B S T R A C T}

\begin{tabular}{|c|}
\hline Keywords \\
\hline $\begin{array}{l}\text { Mugil cephalus, } \\
\text { Livol, } \\
\text { Growth }\end{array}$ \\
\hline Article Info \\
\hline $\begin{array}{l}\text { Accepted: } \\
\text { 15 July } 2018 \\
\text { Available Online: } \\
10 \text { August } 2018\end{array}$ \\
\hline
\end{tabular}

Introduction

Mullets of the family mugilidae offer great potential for brackish water aquaculture. $M$. cephalus forms one of the important commercial fisheries in the estuaries and coastal water of the tropical and sub-tropical regions of all seas. M. cephalus and $M$. tade have been successfully cultured along with penaeid prawns and milk fish, Chanos chanos (Kurian, 1975). High population of mullets is recorded in Gulf of Kutch, Dwarka region, and Diu. There are seven species of mullets available in Gujarat (Gopalkrishanan and Thaker, 1990).

\begin{abstract}
A growth and digestibility study were conducted on fry of grey mullet Mugil cephalus fed with the pelleted feed of $30 \%$ protein content incorporated with herbal liver tonic (Livol) of four different doses viz., 0, 0.5, 1.0 and 1.5\%. Fishes fed with Livol incorporated diets showed higher growth than without 'Livol'. Significantly $(p<0.05)$ superior growth was observed in the fish fed with $1.0 \%$ liver tonic incorporated diet. However there was no significant difference in growth of fish observed in 0.5 and $1.5 \%$ 'Livol' incorporated feed. Lower Hepato somatic index (HIS) and higher Viscerosomatic index (VSI) were recorded in Livol treated fish than without Livol. Highest weight gain, food conversion efficiency, protein efficiency, nutrient digestibility and muscle protein retention were recorded in the fishes treated with $1 \%$ herbal liver tonic (Livol). Whereas highest apparent lipid retention was recorded in the fish fed with $1.5 \%$ Livol incorporated diet.
\end{abstract}

In aquaculture, feed accounts for about $60 \%$ of the production cost (Maheshappa, 1993). The profitability from aquaculture can be significantly increased by employing diets capable of maximizing fish production without increasing input cost. In order to achieve this, several growth promoters such as hormones, antibiotics, vitamins, minerals, enzymes have been tested by various researchers (Maheshappa, 1993). Though, certain hormones and antibiotics have been found to be anabolic, but the fear of residual effects on consumers has limited their usages in commercial diets. This has prompted to search for growth promoting substances which are of natural origins. 
In this context, herbal liver tonic is thought to be a potential one. It is available both in liquid and powdered forms under various brand names like Livol, Liv52, Livton, Zigbo etc. They are claimed to be ideal metabolic stimulant, growth promoter liver tonic improves digestion and assimilation of feed nutrients.

It is hepatic stimulant improving the overall utilization of nutrients hepatic formulated mainly from Boerhuvia diffusa, Solanum nigrum, Terminalla arjuna, Colocynth and black salt (Pandey et al., 1983). It has been reported as a good remedy for hepatic disorders resulting in growth promotion in farm animals (Baishya et al., 1982; Pandey et. al., 1983). Rao and Subba Reddy (1986) opined that addition of Livol to the broiler chick diet had beneficial effect on body weight, feed consumption or feed efficiency. It can be used to prevent or reverse the adverse effects of aflatoxins, growth promotion and improved feed efficiency in broiler (Rao and Subba Reddy, 1990).

Very limited information is available on growth promoting effect of herbal liver tonic in fishes. Abraham (1992) was the first who reported that common carp, Cyprinus carpio fed on a diet containing 1\% Livol showed better growth rate, food conversion ratio and protein efficiency ratio. After that Gireesha (1993), Nandeesha et al., (1992), Maheshappa (1993), Rao (1996), Jayprakash and Euphyasia (1997), Euphyasia and Jayprakash (1999) and Maheshappa et al., (1999, 2002) studied the growth promoting effect of herbal liver tonic 'Livol' on various fresh water finfish. However, such study on brackish water species like mullets is perhaps not recorded. Therefore focusing the light on the importance of Herbal liver tonic 'Livol' to enhance growth in grey mullet $M$. cephalus, the present study was undertaken.

\section{Materials and Methods}

The study was conducted to investigate the effect of different dosages of herbal liver tonic commercially called 'Livol' on growth and biochemical composition of grey mullet, $M$. cephalus through dietary administration. Fine pelleted feed was prepared using ingredients used by Varghese, et al., (1976) and Perera and De Silva (1978) and used as medium for administration of Livol at three dosages viz., $0.5 \%, 1.0 \%$, and $1.5 \%$. The treatments were designated as $\mathrm{T} 0, \mathrm{~T} 1, \mathrm{~T} 2$, and T3 for control $(0 \%), 0.5 \%, 1.0 \%$ and $1.5 \%$ Livol incorporated diet respectively (Table 1).

The basal diet having a protein content of $30.19 \%$ was formulated following the square method (Hardy, 1980). The required quantities of ingredients mixed well, hand kneaded to the required consistency with sufficient water. The resultant dough was cooked for 30 minutes at $105^{\circ} \mathrm{C}$ following the method of Jayaram and Shetty (1981). The cooked dough was cooled to room temperature and added with required quantity of Livol for various doses $(0.5 \%, 1.0 \%$ and $1.5 \%)$ and mixed thoroughly with hand. Simultaneously, vitamin mineral pre-mix was also added and mixed well. The feed mixture was then extruded in the form of pellets using mechanical pelletizer, having a perforation diameter of $2 \mathrm{~mm}$ and dried in electric oven (thermostatically controlled at $60^{\circ} \mathrm{C}$ ) till the moisture content was reduced to less than 10 $\%$. The control diet was prepared in the same manner, but without addition of Livol. The proximate composition of the basal diet analyzed following the standard methods AOAC (2006)

Fry of M. cephalus $(0.054 \pm 0.001 \mathrm{~g}$ and 14 $\mathrm{mm} \pm 0.5)$ were stocked at a density of 1 nos/4 L (Sawant et al., 2003) following CRD statistical method (Snedecor and Cocharan, 1967) in 16 plastic tanks, each containing 80 
L brackish water of 20 ppt salinity (De Silva and Perera, 1976). Before commencement of experiment, the feeding rate protocol was determined using check tray. The fishes were fed once daily in the morning (8.30 a.m.) at the rate of $20 \%$ of body weight for first fifteen days. They were fed at the same time at the rate of $17 \%$ of their body weight for last thirty days.

Water quality was monitored every fortnightly for various physico-chemical parameters, such as temperature, $\mathrm{pH}$, dissolved oxygen, free carbon dioxide and total alkalinity following APHA (1985) procedures. Fish were sampled fortnightly to record the growth. On termination of the experiment after 45 days individual weight of all surviving fish was recorded and representative samples were taken for determining growth, body indices VSI (visceral somatic index) HSI (hepatic somatic index) and muscle proximate composition.

\section{Digestibility study}

A short term experiment was carried out in glass aquaria of the size $0.9 \mathrm{~m} \times 0.4 \mathrm{~m} \times 0.3$ $\mathrm{m}$ for 28 days as per Abraham (1992) and Gireesha (1993) to determine the digestibility of different nutrients. Fry of $M$. cephalus of $0.054 \pm 0.5 \mathrm{~g}$ and $14.5 \pm 0.5 \mathrm{~mm}$ were stocked at the rate of one fish per four liter of water in each aquarium and fed with different levels of Livol incorporated diet as well as the control diet at $20 \%$ of their body weight. After ten hours of feeding, the left over feed was siphoned out and transferred to a pre-weighed and respective numbered of Petridish and kept for oven drying and packed. Faecal matter was siphoned and collected in every morning by filtering the aquarium water through a bolting silk cloth $(20 \mu)$ and kept in well labeled glass Petri dish and kept in oven at $60^{\circ} \mathrm{C}$ for drying. The dried fecal matter was kept in plastic screw bottle according to treatments and replicates. Thus pooled, left over feed and faecal matter from individual experimental aquarium were again oven dried at $55^{\circ} \mathrm{C}$ to remove excessive moisture and weighed at the end of the study. The proximate composition of the faecal matter of each treatment was analyzed following the standard methods (AOAC, 2006).

\section{Results and Discussion}

The major water quality parameters such as temperature $\left(18-23^{\circ} \mathrm{C}\right), \mathrm{pH}(8.1-8.3), \mathrm{DO}(6.8$ $-7.2 \mathrm{ppm})$, Total alkalinity (80.2 -87.58 ppm) and Free carbon dioxide (0.5-1.3 ppm) were within the optimal range as per (Sylvester et.al., 1974) for Mullet fish.

Growth in terms of net weight gain, SGR (Specific growth rate), body indices, FCE (Food conversion efficiency) and nutrient digestibility parameters are presented in Table 2. Significantly superior $(\mathrm{p}<0.05)$ net weight gain, specific growth rate (SGR), Food conversion efficiency and protein efficiency ratio were recorded in all the fish treated with $1.0 \%$ Livol. However above all parameters found higher in all groups fed with Livol incorporated diet than control but reduction was recorded in $1.5 \%$ than other two groups of Livol treated fish. These results are in agreement with Nandeesha (1992), Sambhu and Jayprakash (2001) and Abrham et al., (2001) as they recorded highest growth, SGR (specific growth rate), FCE (Food conversion efficiency) and PER (protein efficiency ratio) in $C$. mrigala $P$. indicus and $C$. carpio respectively at $1 \%$ Livol incorporated diet treatment. Whereas, Maheshppa (1993) and Gireesha et al., (2002) observed significantly highest results in $L$. rohita and $C$. catla respectively treated with $0.5 \%$ Livol incorporated diet.

Reduction in growth beyond optimal level of liver tonic indicates catabolic action at higher levels. There is no effect of Livol on survival fish. The use of anabolic agents as growth 
promoters in fish is known to induce hypertrophy of liver and kidney (Matty and Lone 1979) thereby affecting body indices. Decrease in HSI (Hepato somatic index) was noticed in the Livol treated groups, in comparison to the control. Minimum HSI was observed in $1 \%$ Livol treatment and significantly maximum HSI was observed in control. However there was no significant difference in HSI between 0.5 and $1.5 \%$ Livol incorporated diet treatments. These results are in agreement with Maheshappa (1993), Arbrham et al., (2001), Sambhu and Jayprakas (2001) and Gireesha et al., (2002). Based on the studies on C. carpio, Lone and Matty (1980 a) suggested mobilization of fat from liver to muscle as the possible reason for the decrease in HSI, since muscle lipid increased following steroid feeding. VSI increased as the level of Livol incorporation increased except in $1.5 \%$ Livol incorporated diet treatment. However, higher VSI values were recorded in all Livol treated groups than control. Significant increase in VSI was observed in $1 \%$ Livol incorporated diet treatment.

Several growth stimulants have been found to improve nutrient digestibility in carps (Nandeesha et al., 2000). In the present study significantly highest digestibility of nutrient especially protein was observed in the fish fed with $1 \%$ Livol supplemented feed. This may be the reason for the improvement in protein efficiency ratio in Livol treated fish (Fig. 1$5)$.

\begin{tabular}{|l|c|c|c|}
\hline \multicolumn{3}{|c|}{ Table.1 Ingredients and proximate composition of the basal diet } \\
\hline Ingredients & $(\%)$ & $\begin{array}{c}\text { Proximate } \\
\text { composition }\end{array}$ & $(\%)$ \\
\hline Rice bran & 40 & Moisture & $\mathbf{6 . 7 6} \pm \mathbf{0 . 6 6}$ \\
\hline Fish meal & 25 & Crude protein & $\mathbf{3 0 . 1 9 \pm 0 . 1 8}$ \\
\hline Ground nut Oil cake & 24 & Crude fat & $\mathbf{5 . 9 8} \pm \mathbf{0 . 4 2}$ \\
\hline Tapioca flour & 10 & Crude fibre & $\mathbf{9 . 9 \pm 0 . 6 6}$ \\
\hline Vitamin and mineral mix & 01 & NFE & $\mathbf{2 8 . 3 2} \pm \mathbf{0 . 5 2}$ \\
\hline & & Ash & $\mathbf{1 8 . 8 5} \pm \mathbf{0 . 4 8}$ \\
\hline & & $\begin{array}{c}\text { Calorific } \\
\text { content } \\
\text { (K.Cal/g) }\end{array}$ \\
\hline
\end{tabular}




\begin{tabular}{|c|c|c|c|c|c|c|c|c|}
\hline \multicolumn{9}{|c|}{ Table. 2} \\
\hline \multirow[t]{2}{*}{ Parameters } & \multicolumn{4}{|c|}{ Diets } & \multicolumn{4}{|c|}{ Statistical analysis } \\
\hline & control & $\begin{array}{l}0.5 \% \\
\text { Livol }\end{array}$ & $\begin{array}{l}1.0 \% \\
\text { Livol }\end{array}$ & $\begin{array}{l}1.5 \% \\
\text { Livol }\end{array}$ & S.EM \pm & $\begin{array}{c}\text { CD @ } \\
5 \%\end{array}$ & C.V.\% & Test \\
\hline \multicolumn{9}{|l|}{$\begin{array}{l}\text { Growth and } \\
\text { Feed }\end{array}$} \\
\hline Final weight $(g)$ & $\begin{array}{l}0.291 \\
\pm 0.014\end{array}$ & $\begin{array}{l}0.327 \\
\pm 0.09\end{array}$ & $\begin{array}{c}0.405 \\
\pm 0.012\end{array}$ & $\begin{array}{l}0.349 \\
\pm 0.012\end{array}$ & 0.006 & 0.018 & 3.439 & $*$ \\
\hline $\begin{array}{l}\text { Net weight gain } \\
\text { (g) }\end{array}$ & $\begin{array}{l}0.237 \\
\pm 0.013\end{array}$ & $\begin{array}{l}0.273 \\
\pm 0.01\end{array}$ & $\begin{array}{c}0.351 \\
\pm 0.011\end{array}$ & $\begin{array}{l}0.295 \\
\pm 0.014\end{array}$ & 0.006 & 0.018 & 4.071 & * \\
\hline $\begin{array}{l}\text { Specific growth } \\
\text { rate }(\%)\end{array}$ & $\begin{array}{l}1.62 \\
\pm 0.02\end{array}$ & $\begin{array}{l}1.74 \\
\pm 0.05\end{array}$ & $\begin{array}{l}1.95 \\
\pm 0.02\end{array}$ & $\begin{array}{l}1.80 \\
\pm 0.06\end{array}$ & 0.020 & 0.061 & 2.223 & $*$ \\
\hline $\begin{array}{l}\text { Food } \\
\text { conversion } \\
\text { efficiency }(\%)\end{array}$ & $\begin{array}{l}40.55 \\
\pm 1.99\end{array}$ & $\begin{array}{l}46.28 \\
\pm 1.79\end{array}$ & $\begin{array}{l}59.45 \\
\pm 1.02\end{array}$ & $\begin{array}{l}50.40 \\
\pm 2.7\end{array}$ & 0.983 & 3.030 & 4.000 & $*$ \\
\hline $\begin{array}{l}\text { Protein } \\
\text { efficiency ratio }\end{array}$ & $\begin{array}{l}1.35 \\
\pm 0.07\end{array}$ & $\begin{array}{l}1.53 \\
\pm 0.05\end{array}$ & $\begin{array}{c}1.97 \\
\pm 0.03\end{array}$ & $\begin{array}{l}1.67 \\
\pm 0.09\end{array}$ & 0.031 & 0.096 & 3.835 & $*$ \\
\hline \multicolumn{9}{|l|}{ Body indices } \\
\hline $\begin{array}{l}\text { Hepatosomatic } \\
\text { index }\end{array}$ & $\begin{array}{l}3.41 \\
\pm 0.13\end{array}$ & $\begin{array}{l}2.29 \\
\pm 0.11\end{array}$ & $\begin{array}{l}1.62 \\
\pm 0.26\end{array}$ & $\begin{array}{l}2.31 \\
\pm 0.11\end{array}$ & 0.082 & 0.253 & 6.821 & $*$ \\
\hline $\begin{array}{l}\text { Viscerosomatic } \\
\text { index }\end{array}$ & $\begin{array}{l}7.29 \\
\pm 0.13\end{array}$ & $\begin{array}{l}8.34 \\
\pm 0.21\end{array}$ & $\begin{array}{l}9.39 \\
\pm 0.16\end{array}$ & $\begin{array}{l}8.44 \\
\pm 0.15\end{array}$ & 0.083 & 0.256 & 1.987 & $*$ \\
\hline \multicolumn{9}{|c|}{ Nutrient digestibility } \\
\hline Protein $(\%)$ & $\begin{array}{r}78.16 \\
\pm 2.92\end{array}$ & $\begin{array}{l}86.47 \\
\pm 1.14\end{array}$ & $\begin{array}{l}90.54 \\
\pm 1.39\end{array}$ & $\begin{array}{l}87.82 \\
\pm 1.33\end{array}$ & 0.919 & 2.831 & 2.143 & $*$ \\
\hline Fat $(\%)$ & $\begin{array}{l}80 \\
\pm 4.08\end{array}$ & $\begin{array}{l}85.36 \\
\pm 0.41\end{array}$ & $\begin{array}{l}90.47 \\
\pm 0.37\end{array}$ & $\begin{array}{l}90.35 \\
\pm 0.44\end{array}$ & 1.036 & 3.192 & 2.394 & $*$ \\
\hline $\begin{array}{l}\text { Nitrozen free } \\
\text { extract }(\%)\end{array}$ & $\begin{array}{l}86.21 \\
\pm 0.77\end{array}$ & $\begin{array}{l}88.11 \\
\pm 0.62\end{array}$ & $\begin{array}{l}90.13 \\
\pm 1.85\end{array}$ & $\begin{array}{l}89.05 \\
\pm 1.3\end{array}$ & 0.617 & 1.9 & 1.395 & $*$ \\
\hline \multicolumn{9}{|c|}{ Proximate composition (\%) } \\
\hline Moisture & $\begin{array}{l}74.48 \\
\pm 0.3\end{array}$ & $\begin{array}{l}73.98 \\
\pm 0.11\end{array}$ & $\begin{array}{l}73.60 \\
\pm 0.27\end{array}$ & $\begin{array}{l}73.83 \\
\pm 0.31\end{array}$ & 0.130 & 0.401 & 0.352 & \\
\hline Crude protein & $\begin{array}{l}14.19 \\
\pm 0.15\end{array}$ & $\begin{array}{l}15.09 \\
\pm 0.14\end{array}$ & $\begin{array}{l}16.68 \\
\pm 0.32\end{array}$ & $\begin{array}{l}15.22 \\
\pm 0.33\end{array}$ & 0.101 & 0.311 & 1.320 & $*$ \\
\hline crude fat & $\begin{array}{l}4.12 \\
\pm 0.23\end{array}$ & $\begin{array}{l}4.64 \\
\pm 0.31\end{array}$ & $\begin{array}{l}4.45 \\
\pm 0.12\end{array}$ & $\begin{array}{l}5.24 \\
\pm 0.18\end{array}$ & 0.109 & 0.337 & 4.741 & $*$ \\
\hline NFE & $\begin{array}{l}2.62 \\
\pm 0.27\end{array}$ & $\begin{array}{l}2.13 \\
\pm 0.14\end{array}$ & $\begin{array}{l}1.66 \\
\pm 0.06\end{array}$ & $\begin{array}{l}1.9 \\
\pm 0.08\end{array}$ & 0.079 & 0.245 & 7.645 & \\
\hline Ash & $\begin{array}{l}4.6 \\
\pm 0.29\end{array}$ & $\begin{array}{l}4.16 \\
\pm 0.38\end{array}$ & $\begin{array}{l}3.62 \\
\pm 0.1\end{array}$ & $\begin{array}{l}3.67 \\
\pm 0.22\end{array}$ & 0.133 & 0.411 & 6.650 & \\
\hline
\end{tabular}




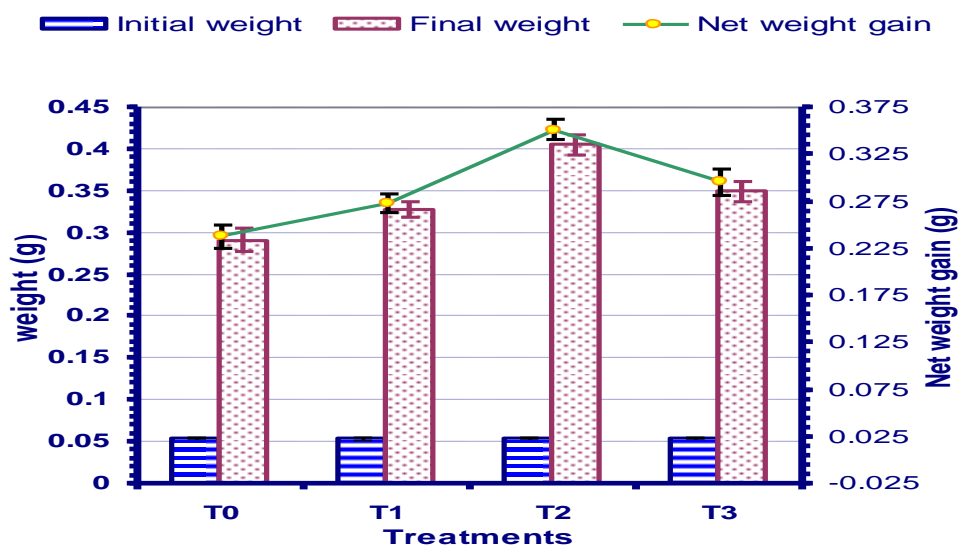

Fig.1 The initial, final and net weight gains of $M$. cephalus in different treatments (mean \pm S.D.)

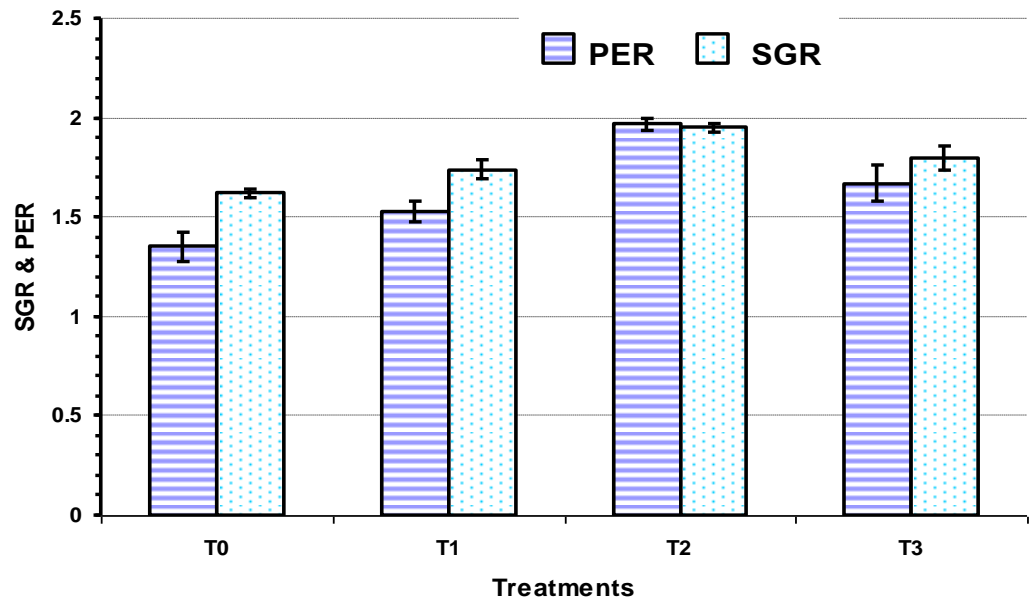

Fig.2 PER (protein efficiency ratio) and SGR (specific growth rate) of $M$. cephalus fry in different diet treatments (mean \pm S.D.)

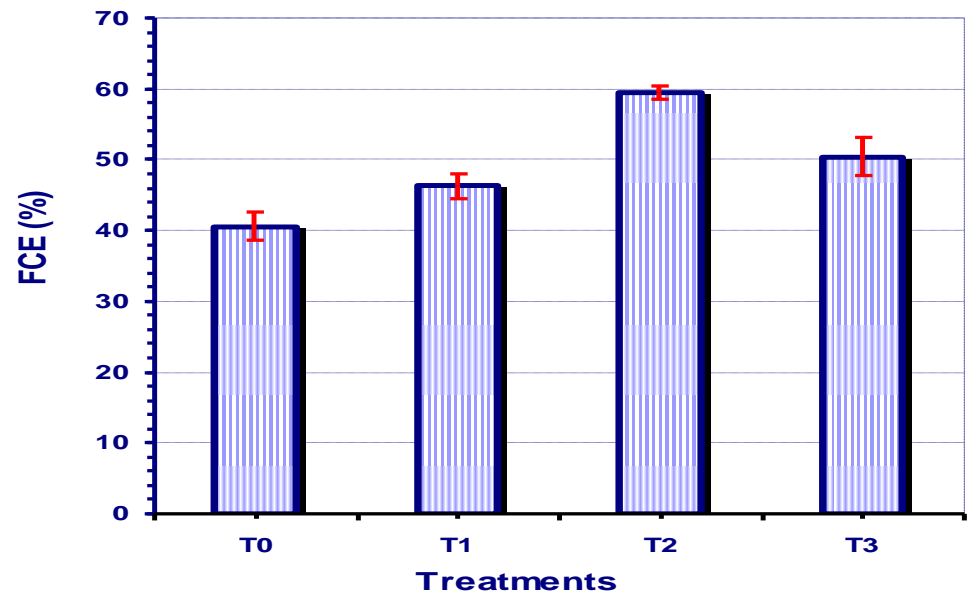

Fig.3 FCE (food conversion efficiency) of $M$. cephalus in different treatments (mean \pm S.D.) 


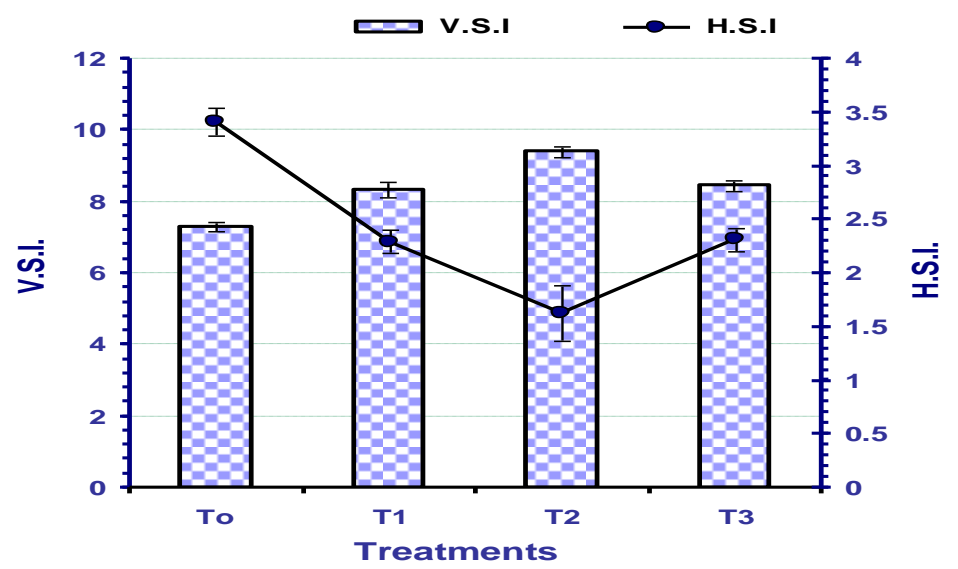

Fig.4 Body indices, H.S.I. (hepatosomatic index) and V.S.I. (viscero- somatic incdex) of $M$. cephalus reared in different treatments (mean $\pm \mathrm{SD}$.)

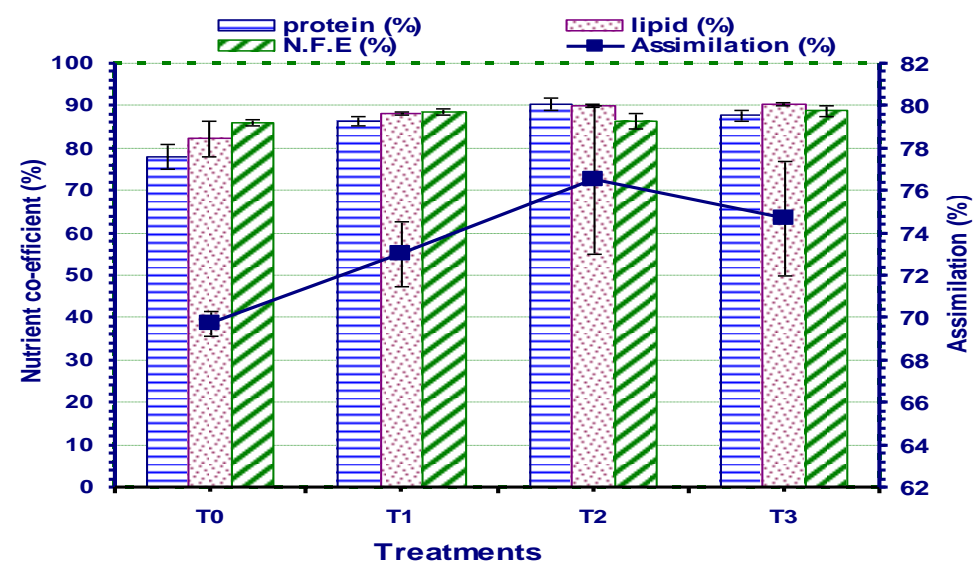

Fig.5 Digestion co-efficient of nutrients and food assimilation efficiency in fry of $M$. cephalus under different treatments (mean \pm SD.)

As far as proximate composition of muscle revealed that significantly highest protein and lowest moisture were recorded in the fish fed with the diet incorporated with $1 \%$ Livol. However, there was no significant difference between 0.5 and $1.5 \%$ Livol incorporated diet treatments for protein deposition. Since fish growth is due to enhanced protein synthesis a possible change in biochemical composition and protein content could be expected between treatments (Lone and Matty, 1980a). Abraham et al., (2001) recorded higher protein content in C. carpio on $1 \%$ Livol incorporated diet feeding. Nandeesha (1992), Maheshappa (1993) and Gireesha et al.,
(2002) observed higher protein content in fish fed with Livol incorporated diets. Thus a change in the protein content could be accredited to the varying levels of Livol in the diets.

Significantly superior fat content was observed in $1.5 \%$ Livol incorporated diet treatment and the lowest in the control. These results are in agreement with Gireesha (1993) and Rao (1996) as they recorded higher fat content in $C$. catla and $C$. batrachus respectively fed with the diets containing Livol $(0.5,1.0$, and $1.5 \%)$ as compared to control. While, Abraham, (1992) recorded 
lower value of muscle fat content in $C$. carpio fed with Livol incorporated (0.5 to $1.5 \%)$ diets compared to control (without Livol incorporation).

Lone and Matty (1980a) who reported mobilization of fat from liver to fish muscle. It is known that muscle lipids increase during fish growth. This has been reported in $M$. cephalus by Perera and De Silva (1978).

\section{References}

Abraham, S. (1992). Effect of Livol on growth and body composition of common carp, Cyprinus carpio (Linn.). M.F.Sc Thesis submitted to University of Agricultural Sciences, Bangalore, $103 \mathrm{pp}$.

Abraham, S., Ramesha, T.J., Gangadhara, B., and Varghese, T.J. (2001). Growth response of common carp, Cyprinus carpio (Linn.) to varied levels of Livol, a non-hormonal growth promoter. Indian Journal of Fisheries, 48(4):397-401.

AOAC (2006). Official methods of analysis, $18^{\text {th }}$ Edition. Washington D.C.,1094 pp.

APHA (1985). Standard methods for the examination of water and waste water. $16^{\text {th }}$ American Public Health Association, Washington DC.

Baishya, B., Barua, S.K., Thakuria, R.N. and Hussain, A. (1982). Use of Livol in hepatic disorders and malfunction in animals. Pashudhan, 8:67.

De Silva, S.S. and Perera, P.A.B. (1976). Studies on the biology of young grey mullet, Mugil cephalus (L.). II. Effect of salinity on food intake, growth and food conversion. Aquaculture 7:327-338.

Euphyasia, C.J. and Jayprakash, V. (1999).Growth responses of the Indian major carp (Cirrhinus mrigala) to Livol (IHF-1000). Proceedings of The Fourth Indian Fisheries Forum, Kochi, Kerala. pp. 303-305.

Gireesha, O. (1993). Effect of Livol on growth and biochemical composition of Catla catla (Ham.). M.F.Sc. Thesis submitted to
University of Agricultural Sciences, Bangalore, $144 \mathrm{pp}$.

Gireesha, O., Ramesha, T.J., Varghese, T.J. and Manjappa, K. (2002). Impact of dietary Livol on the growth, biochemical composition and gut digestive enzyme activity of Catla (Catla catla). Journal of Aquaculture in Tropics, 17(1): 35-42.

Gopalkrishnan, P. and Thaker, S.R. (1990). Studies on the maturation and spawning of grey mullets of a reservoir fishery in Okhamandal (Gulf of Kutch) with special reference to rural development along the coast. CMFRI Bulletin, 44(2):58-65.

Hardy, R. (1980.). Fish feed formulation. Paper presented at the FAO/UNDP Training Course in Fish Feed Technology, Seattle, W.A., U.S.A., ADCP/REP/80, 11: 8.

Jayprakas, V. and Euphrasia, C.J. (1997). Growth performance of Labeo rohita (Ham.) to Livol (IHF-1000), a herbal product.Proceedings of the Indian National Science Academy. Part B. Biological Sciences. 63 (1, 2): 21-30 pp.

Jayram, M.G. and Shettey, H.P.C. (1981). Formulation, processing and water stability of two new feeds. Aquaculture, 23: 355-359.

Kurian, C. V. (1975). Mullet fisheries of India. Aquaculture, 5(1): 114.

Lone, K.P. and Matty, A.J. (1980a). The effect of feeding methyltestosterone on the growth and body composition of common carp (Cyprinus carpio L.). General and Comparative Endocrinology., 40(4): 409424.

Maheshppa, K. (1993). Effect of different dosages of Livol on growth and body composition of Rohu, Labeo rohita (Ham.). M.F.Sc Thesis, submitted to University of Agricultural Sciences, Bangalore, $122 \mathrm{pp}$.

Maheshppa, K., Ramesh, T.J., Gangadhar, B. and Verghese, T.J. (1999). Growth performance and biochemical composition of rohu, Labeo rohita to Livol incorporated diets. Indian Journal of Animal Sciences, 27:113-117.

Maheshppa,K., Ramesh, T.J., Gangadhar, B. 
and Verghese, T.J. (2002). Effect of feeding Livol incorporated diet on nutrient digestibility, body indices and organoleptic quality of rohu, Labeo rohita. Indian Journal of Fisheries, 49(4):447-450.

Matty, A.J. and Lone, K.P. (1979). The effect of some steroid hormones on the growth and protection metabolism of rainbow trout. Aquaculture, 14: 163-178.

Nandeesha, M.C., Gangadhara, B. and Dathathri (1992). Effect of Livol on growth and body composition of mrigal, Cirrhinus mrigala (Linn.). (Personnal communication). Quated by Gireesha, O. (1993). M.F. Sc Thesis, University of Agricultural Sciences, Bangalore, $144 \mathrm{pp}$.

Nandeesha, M.C., Gangadhara, B., Keshavanath, P. and Varghese, T. J. (2000). Effect of dietary sodium chloride supplementation on growth, biochemical composition and digestive enzyme activity of young Cyprinus carpio (Linn.) and Cirrhinus mrigala (Ham.) J. Aqua. Trop., 15: 135-144

Pandey, G.P., Shrivastava, P.N. Shrivastava, A.M., Sharma, J.J. and Shrivastava, A.B. (1983). Effect of Livol on some biochemical parameters of liver functions. Indian Veterinary Journal, 60:978.

Perera, P.A.B. and De Silva, S.S. (1978). Studies on the chemical biology of young grey mullet, Mugil cephalus (Linn.). Journal of Fish Biology, 13:297-304.

Rao, A.S. (1996). Effect of different dosages of
Livol on growth and bio-chemical composition of fry of Clarius batrachus. M.F.Sc Thesis submitted to Orissa Univerisity of Agricultural Technology, Bhubaneswar, 108 pp.

Rao, P.V. and Rama Subba Reddy, V.I., (1990). The effect of Livol on the performance of broiler chicken. Pashudhan, 5(1):27.

Sambhu, C. and Jayprakash, V. (2001). Livol (IHF-1000), a new herbal growth promoter in white prawn, Penaeus indicus. Indian Journal of Marine Science, 30:(1), 38-43 pp.

Sawant, G.P., Singh, H., Sawant, N.H. and Yusufzai, S.I. (2003). Bioenergetic studies on the fry of Liza parsia (Hamilton- Buchanan, 1822) using three different oil cakes. Indian Journal of Applied and Pure Biology, 18(2):169-178.

Sylvester, J.R., Nash, C.E. and Emberson, C.E. (1974). Preliminary study of temperature tolerance in juvenile Hawaiian mullet (Mugil cephalus). Progressive Fish Culturist, 36(2): 99-110.

Varghese, T.J., Devraj, K.V., Shantaram, B. and Shetty, H.P.C., (1976). Growth response of common carp, Cyprinus carpio var. Communist to protein-rich pelleted feed. Paper presented at the symposium on Development and Utilization of Indian Fishery Resources, Colombo (Sri Lanka). FAO Regional Office for Asia and the Far East, Bangkok, Thialand, 408-416 pp.

\section{How to cite this article:}

Prakash P. Patel, Mukesh P. Patel and Tank, P.R. 2018. Effect of Herbal Liver Tonic on the Growth, Digestibility and Bio-chemical Composition of Grey Mullet Mugil cephalus (Linnaeus) Fry. Int.J.Curr.Microbiol.App.Sci. 7(08): 2741-2749.

doi: https://doi.org/10.20546/ijcmas.2018.708.287 